\title{
Računalne provjere znanja u sustavu Moodle u kontekstu diferencijacije vrednovanja
}

\author{
Gabrijela Marin ${ }^{1}$, Sanja Fabac ${ }^{2}$ \\ ${ }^{1}$ Medicinska škola Ante Kuzmanića, Zadar, Republika Hrvatska \\ gabrijela.marin@skole.hr \\ ${ }^{2}$ Gimnazija Vladimira Nazora, Zadar, Republika Hrvatska
}

\begin{abstract}
SAŽETAK
Istraživanje je provedeno tijekom nastave na daljinu (školske godine 2019./2020.), na uzorku od 49 učenika dvaju prvih razreda Medicinske škole Ante Kuzmanića, u Zadru. Cilj istraživanja je bio empirijski istražiti mogućnost korištenja brzih računalnih provjera u pristupu vrednovanju naučenog, u uvjetima pandemije. Tijekom četiri tjedna učenici su poučavani asinkrono-korištenjem digitalnih sadržaja u digitalnoj bilježnici (OneNote Class Notebook) i sinkrono-korištenjem video poziva. Uspješnost online poučavanja provjerena je rješavanjem tri vremenski ograničene računalne provjere, u sustavu Moodle. Svaka od računalnih provjera sadržavala je određen omjer pitanja koja provjeravaju različite kognitivne razine. Nakon što su učenici riješili računalnu provjeru srednje razine, morali su odabrati računalnu provjeru osnovne ili napredne razine. Rezultati istraživanja pokazuju da unatoč detaljno razrađenim aktivnosti učenika i nastavnika u online poučavanju, nastava na daljinu nije rezultirala željenim ishodima, odnosno postotak ukupne riješenosti u svakoj od tri računalne provjere je bio manji od 50\%. Suprotno postavljenoj hipotezi učenici najveća postignuća ostvaruju u računalnoj provjeri srednje razine, a broj sati koje je nastavnik koristio za poučavanje nije utjecao na postignuća učenika. U skladu s postavljenom hipotezom učenici najbolje rješavaju zadatke prve kognitivne razine. Unatoč dobivenim rezultatima, platforma za učenje Moodle, u kojoj nastavnik može kreirati banku zadataka različitih kognitivnih razina, otvara put za diferencijaciju vrednovanja u skladu s različitim potrebama i interesima učenika.
\end{abstract}

Ključne riječi: računalne provjere; vrednovanje naučenog; kognitivne razine; diferencijacija; Moodle

\section{UVOD}

Jedno od najvažnijih nastavnih umijeća jest vrednovanje učeničkih postignuća. Međutim, dosadašnja dokimološka praksa nije se pokazala uspješnom jer je umjesto procesa učenja fokus djelovanja i učenika i nastavnika bio usmjeren na konačni rezultat. Tako je svaki učenik na kraju nastavne godine za svoj rad bio ocijenjen jednom brojkom na skali ocjena od 1 do 5, dok je nastavnik imao ulogu mjernog instrumenta koji tu ocjenu određuje (Grgin, 1994).

Kurikulumski orijentiran obrazovni sustav donio je nove pristupe vrednovanja u kojem se svako vrednovanje treba temeljiti na cjelovitome pristupu praćenja i poticanja individualnoga razvoja svakoga učenika te se usmjerava na prepoznavanje uspjeha i poticanje pozitivnih obrazaca motivacije i učenja . Apostrofiranje individualnog pristupa u procesu poučavanja i vrednovanja pred nastavnike je stavilo novi izazov. Razredni odjel čine učenici vrlo različitih sposobnosti, predznanja i motivacije, učenici koji savladavaju odgojno obrazovne ishode predmetnog kurikuluma različitim tempom $\mathrm{i}$ stilovima učenja. lako su pojedini nastavnici za potrebe vrednovanja naučenog diferencirali pisane provjere smanjivanjem ili povećavanjem broja zadataka i/ili težine zadataka, to nije diferencijacija u pravom smislu riječi. Postavlja se pitanje kako provesti diferencijaciju vrednovanja naučenog $u$ razrednom odjelu, kojeg čini iznimno heterogena skupina učenika. Vrednovanje naučenoga jest sumativno vrednovanje kojemu je svrha procjena ostvarenosti ishoda nakon određenoga razdoblja učenja i poučavanja. S obzirom da ga osmišljava, planira i provodi učitelj govorimo o unutarnjem vrednovanju, gdje nastavnik ima mogućnost korištenja velikog broja metoda. Ukoliko se prema načelu praktičnosti odlučimo za pisanu provjeru, postavlja se pitanje konstrukcije takve pisane provjere, 
provedbe i evaluacije. S obzirom na to da su sve škole opremljene računalima te da infrastruktura postoji, kao jedno od rješenja mogu poslužiti digitalni alati za vrednovanje.

Online vrednovanje (engl. Online assessment ili E- assessment) je novija metoda vrednovanja učeničkih postignuća. Može poslužiti za inicijalno provjeravanje, provjeravanje na kraju nastavne teme, za brzu dijagnostiku potrebnih odgojno-obrazovnih ishoda ili sustavno praćenje njihove ostvarenosti jer omogućava brzu i jednostavnu obradu podataka (Buzzetto-More, 2006). lako online vrednovanje ima veliki potencijal, kada se koristi u sumativne svrhe zahtijeva visoki stupanj kontrole kako bi se osigurala valjanost i pouzdanost ostvarenih rezultata. Najčešći nedostaci u provedbi odnose se na izostanak komunikacije s nastavnikom za vrijeme provjeravanja, teškoće $s$ internetskom vezom te mogućnost prepisivanja (Casady i Gridley, 2005). lako učenici u pravilu imaju pozitivan stav prema online vrednovanju, kao veliki problem navode loše konstruirane zadatke $u$ ispitnim bazama (Dermo, 2009) čime se umanjuje objektivnost vrednovanja te češća primjena u nastavnoj praksi. U hrvatskim okvirima računalne provjere ne promatraju se izolirano već kao jedna od brojnih aktivnosti u nekom od sustava e - učenja (Bulić, 2018; Ivić i Tomaš, 2017; Kokan i sur, 2014).

\section{Konstrukcija računalnih provjera}

Razvoj softvera omogućio je konstrukciju računalnih provjera koje se danas sadržajno ne razlikuju od uobičajene pisane provjere. Ipak, umjesto papira i olovke, računalnu provjeru učenici rješavaju pomoću radne površine (desktopa) računala i tipkovnice. U didaktičkom pogledu ne može se više govoriti o didaktičkom trokutu koji čine učitelj, učenik i nastavni sadržaj već o didaktičkom četverokutu koji čine učenik, učitelj, nastavni sadržaj i obrazovna tehnologija (Matijević i Topolovčan, 2017).

Prilikom planiranja računalne provjere nastavnik bi trebao slijediti iste didaktičko-metodičke smjernice kao i kod metode papir-olovka. To podrazumijeva uvažavanje teorije konstruktivizma u osmišljavanju procesa učenja i ciljeva učenja. Konstruktivistički pristup nastavi počiva na pretpostavci da se proces učenja odvija temeljem osobne konstrukcije i rekonstrukcije znanja koje nastaje kao rezultat učeničkih interakcija s prirodnim svijetom u određenom sociokulturnom kontekstu, uz dinamičko posredovanje njihovih prethodnih znanja (Jukić, 2013). U odabiru odgojno-obrazovnih ishoda čiju usvojenost želi provjeriti nastavnik treba pripaziti da su odgojno-obrazovni ishodi usklađeni s načinom poučavanja i vrednovanja njihove ostvarenosti u tzv. kurikulumskom (konstruktivnom) poravnanju (engl. constructive alignment) (Andersen, 2002).

Konstrukcija računalne provjera zahtijeva i odgovarajuću digitalnu podršku koju u najužem smislu čine uređaj za vrednovanje (hardver, softver) i banka zadataka (Howarth, 2015). Veliki napredak informacijske i komunikacijske tehnologije rezultirao je pojavom brojnih digitalnih alata za izradu brzih i jednostavnih testova/kvizova. Nastavnik ima mogućnost izbora, a alati se razlikuju ovisno o vrsti zadataka, kriterijima vrednovanja, statističkoj obradi i prikazu izvještaja (Tomaš, 2018). Za razliku od jednostavnih aplikacija koje svojim korisnicima omogućuju samo jednu aktivnost u pristupu vrednovanja za učenje i vrednovanja kao učenje, platforma za e-učenje Moodle nudi daleko više. Moodle (eng. Modul Object-Oriented Dynamicse Learning Environment) je sustav e-učenja, za koji je CARNet odabrao ime Loomen. lako je 2012. godine Carnet u verziji Moodle 2.0 ponudio različite alate za vrednovanje (Jugo i sur, 2012), tek nakon 2015. godine i projekta e-Škole, započinje njihova primjena u nastavnoj praksi. Loomen nastavnici primarno koriste za kreiranje online tečajeva, iako nastavnik može odabrati i samo jednu aktivnost za svoje polaznike. Ukoliko se odluči za "test “ nastavnik zapravo kreira pisanu provjeru tako da upisuje naziv testa i zatim određuje sve ostale parametre u skladu sa svojim potrebama. U glavnom izborniku „Uredi postavke“, u podizborniku 
"Ocjena" nastavnik odlučuje o minimalnom broju bodova koji učenik mora postići i broju pokušaja rješavanja. U podizborniku „Karakteristike pitanja“ nastavnik se može odlučiti za promjenu redoslijeda pitanja i načinu prikaza povratne informacije učenicima o tome koliko je učenik bio uspješan uz prikaz točnog odgovora i ostvaren broj bodova. U podizborniku „Vrijeme“ nastavnik odlučuje o vremenu početka i završetka aktivnosti, odnosno može ograničiti vrijeme u kojem će test biti dostupan učenicima (Tomaš, 2018).

Najvažniji korak u kreiranju računalne provjere jest izrada banke zadataka. Nastavnik odabire vrstu zadatka ovisno o programskim mogućnostima aplikacije, odnosno platforme e-učenja, kao i o odgojnoobrazovnim ishodima koje želi provjeriti. Upravo oblikovanje zadataka kojima se nastoji provjeriti usvojenost odgojno obrazovnih ishoda nastavnicima može predstavljati najveći izazov. Poznavanje prednosti i nedostataka različitih vrsta zadataka preduvjet je uspješne konstrukcije svake pisane provjere. lako se zadatcima otvorenog tipa može provjeriti više kognitivnih razina, odgovore učenika je teško bodovati. $S$ druge strane zadatke zatvorenog tipa je teže sastaviti, ali je njihovo bodovanje lakše (Begić i sur, 2019). Nakon uređivanja zadatka, svaki od zadataka autor može svrstati u određenu kategoriju npr. prema vrsti sadržaja, kognitivnoj zahtjevnosti ili nekom drugom kriteriju. Prilikom osmišljavanja zadataka, važno je da zadatak ne provjerava samo reproduktivna znanja. U nastavi Biologije većinom se koristi pojednostavljena Bloomova taksonomija prema kojoj se razlikuju tri kognitivne razine - od razine reproduktivnog znanja, razine konceptualnog razumijevanja do razine rješavanja problema (Radanović i sur, 2018, prema Crooks, 1988). Posljednjih godina provedena su istraživanja postignuća hrvatskih učenika u području Biologije s obzirom na kognitivne razine koje se provjeravaju određenim zadatkom. Jedan dio objavljenih radova pokazuje kako učenici jednako loše ili dobro rješavaju zadatke neovisno o kognitivnoj razini (Bulić 2018a; Golubić i sur, 2017), dok se u drugima naglašava kako uspješnost učenika u rješavanju zadataka opada s porastom kognitivne razine te da su učenici najuspješniji pri rješavanju zadataka prve kognitivne razine (Begić i sur, 2016; Grgurić i sur, 2017; Radanović i sur, 2018).

Provedeno istraživanje imalo je za cilj empirijski istražiti mogućnost korištenja brzih računalnih provjera u vrednovanju naučenog, u uvjetima pandemije. $U$ otegotnim okolnostima nastave na daljinu, korištenjem pitanja različitih kognitivnih razina pokušat će se utvrditi može li online poučavanje utjecati na kvalitetu stečenih znanja i vještina, odnosno razinu ostvarenosti željenih ishoda. Također će se provjeriti mogu li računalne provjere poslužiti kao metoda u diferencijaciji vrednovanja, s obzirom da takve provjere znanja mogu biti različite razine zahtjevnosti i tako prilagođene različitim potrebama učenika u jednom razrednom odjelu.

\section{METODE}

Za potrebe istraživanja izrađene su tri varijante računalne provjere znanja kojim su provjeravani isti odgojno-obrazovni ishodi, ali s tom razlikom što je svaka varijanta sadržavala različiti omjer zadataka na različitim kognitivnim razinama. Učenici su prvo pristupili rješavanju računalne provjere srednje razine, nakon čega su imali mogućnost izbora računalne provjere koja najviše odgovara osobnoj procjeni stečenih znanja i vještina. Kako bi se provjerila kriterijska valjanost računalne provjere kao mjernog instrumenta, ostvareni broj bodova svakog učenika uspoređen je s zaključnom ocjenom predmeta, u e-dnevniku.

U skladu s tim postavljene su sljedeće hipoteze:

kada imaju mogućnost izbora, učenici najčešće biraju računalnu provjeru osnovne razine učenici će ostvariti najveću riješenost u računalnoj provjeri osnovne razine 
u svim računalnim provjerama znanja učenici najuspješnije rješavaju zadatke prve kognitivne razine

postignuća učenika pokazuju korelaciju s brojem školskih sati u online poučavanju

postignuća učenika u računalnoj provjeri srednje razine biti će u korelaciji s zaključnom ocjenom iz biologije.

Za svaku računalnu provjeru izračunati su deskriptivni statistički parametri (aritmetička sredina, medijan, mod, standardna devijacija, koeficijent varijabilnosti, simetričnost i zaobljenost). Psihometrijska svojstva zadataka izražena su preko indeksa lakoće, prema frekvenciji točnih odgovora. Za utvrđivanje korelacije između postignuća učenika i varijable zaključne ocjene premeta te broja školskih sati online poučavanja, primijenjen je Spearmanov koeficijent korelacije, odnosno za utvrđivanje razlike između postignutih rezultata Mann-Whitney test. S obzirom na to da su školske ocjene podaci izraženi na ordinalnoj ljestvici, automatski su primijenjeni navedeni neparametrijski testovi, odnosno nije se pristupilo provjeri normalnosti raspodjele podataka korištenih varijabli. $\mathrm{S}$ druge strane, varijabla broj bodova u računalnoj provjeri srednje razine je skalarna ljestvica podataka za koju su korišteni Shapiro-Wilkov i Lilieforsov test pri ispitivanju normalnosti raspodjele. Za statističku obradu podataka korišten je računalni program Statistica 13.5.

\section{Uzorak ispitanika}

Istraživanje je provedeno na uzorku od 49 učenika dvaju prvih razreda strukovne škole, Medicinske škole Ante Kuzmanića Zadar. U odabiru uzorka ispitanika glavni kriterij je bio da učenici trebaju usvojiti iste odgojno-obrazovne ishode (MZO, 2019), koji su vezani za građu i ulogu jezgre te stanične diobe. lako su navedeni sadržaji sastavni dio odgojno-obrazovnog ishoda BIO OŠ A.8.1., B.8.4. (kurikuluma biologije osmog razreda ) i BIO SŠ B.3.3. (kurikuluma biologije trećeg razreda gimnazije), učenici koji su sudjelovali u istraživanju poučavani su prema nastavnom planu i programu iz 2006. godine. lako su odgojno obrazovni ishodi poučavanja bili jednaki u oba razreda, broj sati online nastave razlikovao se sukladno njihovim programima. Učenici 1. a razreda, upisani u program medicinska sestra/tehničar opće njege, prema nastavnom planu imaju 3 sata biologije tjedno, dok učenici 1. c razreda, upisani u program fizioterapeutski tehničar, imaju 2 sata biologije tjedno. Prije provedbe istraživanja učenici su upoznati s ciljem istraživanja i metodologijom te je svim učenicima zajamčena anonimnost podataka s obzirom na korištenje rezultata iz računalnih provjera.

\section{Mjerni instrumenti}

Za izradu računalnih provjera korištena je platforma za e-učenje Loomen zbog programskih mogućnosti koji se odnose na administraciju testa i analizu rezultata. Nakon otvaranja tečaja naziva Vrednovanje mitoza i mejoza (Blaće i sur, 2019) kreirana je banka zadataka različitih kognitivnih razina. lako su, prema prvotnom planu istraživanja, autorice namjeravale primijeniti smjernice za izradu pitanja (Begić i sur, 2019; Radanović i sur, 2013) po kojem pisana provjera treba sadržavati sve tri kognitivne razine Crooksove taksonomije, ipak su zadatci kognitivno najzahtjevnije, treće razine, svedeni na minimum zbog otežanih uvjeta nastave na daljinu. Tako su u banci zadataka kreirane tri kategorije: zadatci kojima se provjerava razina reproduktivnog znanja, zadatci kojima se provjerava razina konceptualnog razumijevanja i zadatci rješavanja problema. Iz banke zadataka naposljetku su oblikovane tri varijante računalne provjere koje su klasificirane kao osnovna razina, srednja razina i napredna razina - Kao što se vidi u prilogu 1 svaka varijanta računalne provjere sadrži osam pitanja. U tablici 1 prikazana je struktura računalnih provjera gdje osnovna razina sadrži pet pitanja prve kognitivne razine i tri pitanja druge kognitivne razine, srednja razina sadrži četiri pitanja prve i druge kognitivne razine, dok napredna razina sadrži tri pitanja prve kognitivne razine, četiri pitanja druge kognitivne razine i jedno pitanje 
treće kognitivne razine. Pitanje treće kognitivne razine je pojednostavljeno u skladu s programom biologije u strukovnim školama te se odnosi na vještinu čitanje grafikona (MPIŠ RH, 1997).

Tablica 1 Struktura računalnih provjera (engl. Blueprint) prema kognitivnim razinama (Crooks, 1988)

\begin{tabular}{|c|c|c|c|}
\hline $\begin{array}{l}\text { Računalne } \\
\text { provjere }\end{array}$ & $\begin{array}{l}\text { pitanja } 1 . \text { kognitivne } \\
\text { razine (reprodukcija) }\end{array}$ & $\begin{array}{l}\text { pitanja } 2 . \text { kognitivne } \\
\text { razine (konceptualno } \\
\text { razumijevanje) }\end{array}$ & $\begin{array}{l}\text { pitanja } 3 . \text { kognitivne } \\
\text { razine (rješavanje } \\
\text { problema) }\end{array}$ \\
\hline qf $=\left\{\begin{array}{c}\text { osnovna } \\
\text { razina }\end{array}\right.$ & 5 & 3 & 0 \\
\hline r razina & 4 & 4 & 0 \\
\hline "ण" napredna & 3 & 4 & 1 \\
\hline
\end{tabular}

Kategorizacija zadataka prema kognitivnim razinama zahtijevala je više vremena od planiranog. Početne verzije su mijenjane više puta, u skladu s uputama za oblikovanje pisane provjere iz biologije (Begić i sur, 2013; Radanović i sur, 2018; Ristić-Dedić i sur, 2011), sve dok se provjere znanja nisu prilagodile učenicima strukovne škole, a da pri tome ipak zadrže odgovarajuću razinu kognitivne složenosti u skladu s ishodima državne mature iz biologije (NCVVO, 2020. U svim računalnim provjerama korištena je samo jedna vrsta zadatka - zadaci višestrukog izbora $s$ jednim točnim odgovorom (engl. Multiple choice questions, MCQ), svako pitanje nosilo je jedan bod pa je maksimalan broj bodova u svakoj provjeri iznosio osam bodova. Jedan od razloga jednakog bodovanja svih zadataka jest da se time nastojala postići veća varijabilnost postignuća s obzirom na kategorije kognitivnih razina.

\section{Eksperimentalni postupak}

Sve etape istraživanja provedene su online. Od 19. ožujka 2020. kada se započelo s nastavom na daljinu, učiteljsko vijeće u suradnji s profesorom informatike odlučilo se za korištenje programskog paketa Office 365. Od ponuđenih aplikacija odabrane su OneNote Class Notebook (razredna bilježnica) - za isporuku digitalnih obrazovnih sadržaja i Microsoft Teams - za potrebe asinkrone i sinkrone komunikacije. Nakon razdoblja prilagodbe, u kojem su svi učenici dobili svoje korisničke račune i lozinke, 27. travnja započelo se s eksperimentalnim postupkom koji je sadržavao različite aktivnosti u razdoblju od sedam tjedana.

Tablica 2 Hodogram aktivnosti učenika i nastavnice

\begin{tabular}{|c|c|c|c|}
\hline TJEDAN & \multicolumn{2}{|c|}{ UČENIK } & NASTAVNIK \\
\hline $\begin{array}{l}\text { 1. tjedan } \\
\text { 27. travnja - } 30 . \\
\text { travnja }\end{array}$ & \multicolumn{2}{|c|}{$\begin{array}{l}\text { - upoznavanje učenika s načinom korištenja digitalnih } \\
\text { alata (OneNote Class Notebook, Microsoft teams, Zoom) }\end{array}$} & $\begin{array}{c}\text { - online demonstracija korištenja digitalnih alata za } \\
\text { poučavanje i komunikaciju s nastavnicom } \\
\text { (Zoom - VIDEO POZIV) }\end{array}$ \\
\hline $\begin{array}{l}\text { 2. tjedan } \\
\text { 4vibnja - } 8 \text {. } \\
\text { svibnja }\end{array}$ & $\begin{array}{c}\text { 1. a. } \\
\text { OneNote Class Notebook } \\
\text { (domaća zadaća - tri } \\
\text { problemska pitanja) }\end{array}$ & $\begin{array}{c}\text { 1. c. } \\
\text { OneNote ClassNotebook } \\
\text { (domaća zadaća - tri } \\
\text { problemska pitanja) }\end{array}$ & $\begin{array}{c}\text { - planiranje i priprema digitalnih sadržaja } \\
\text { (jezgra, nasljeđivanje, udvostručavanje DNA) } \\
\text { - online poučavanje (Zoom -VIDEO POZIV) } \\
\text { - vrednovanje za učenje i vrednovanje kao } \\
\text { učenje }\end{array}$ \\
\hline $\begin{array}{l}\text { 3. tjedan } \\
\text { 11. svibnja - } 15 \text {. } \\
\text { svibnja }\end{array}$ & $\begin{array}{c}\text { 1. a. } \\
\text { OneNote Class Notebook } \\
\text { (domaća zadaća - crtanje } \\
\text { faza mitoze, problemska } \\
\text { pitanja) }\end{array}$ & $\begin{array}{c}\text { 1. c. } \\
\text { OneNote Class Notebook } \\
\text { (domaća zadaća - crtanje } \\
\text { faza mitoze) }\end{array}$ & $\begin{array}{c}\text { - planiranje i priprema digitalnih sadržaja (stanični } \\
\text { ciklus, mitoza) } \\
\text { - online poučavanje (Zoom -VIDEO POZIV) } \\
\text { - vrednovanje za učenje i vrednovanje kao } \\
\text { učenje }\end{array}$ \\
\hline $\begin{array}{l}\text { 4. tjedan } \\
\text { 18. svibnja - } 22 \text {. } \\
\text { svibnja }\end{array}$ & $\begin{array}{c}\text { 1. a. } \\
\text { OneNote } \\
\text { Class Notebook (domaća } \\
\text { zadaća-Venov dijagram) }\end{array}$ & $\begin{array}{c}\text { 1. c. } \\
\text { OneNote } \\
\text { Class Notebook } \\
\text { (domaća zadaća-sažetak) }\end{array}$ & $\begin{array}{c}\text { - planiranje i priprema digitalnih sadržaja (mejoza) } \\
\text { - online poučavanje (Zoom -VIDEO POZIV) } \\
\text { - vrednovanje za učenje i vrednovanje kao } \\
\text { učenje }\end{array}$ \\
\hline $\begin{array}{l}\text { 5. tjedan } \\
\text { 25. svibnja - } 29 \text {. } \\
\text { svibnja }\end{array}$ & $\begin{array}{c}\text { 1. a. } \\
\text { OneNote } \\
\text { Class Notebook (nastavni } \\
\text { listić za ponavljanje) }\end{array}$ & $\begin{array}{c}\text { 1. c. } \\
\text { OneNote } \\
\text { Class Notebook (nastavni } \\
\text { listić za ponavljanje) }\end{array}$ & $\begin{array}{c}\text { - online ponavljanje (Zoom -VIDEO POZIV) } \\
\text { - analiza izrađenih računalnih provjera } \\
\text { (završni odabir najkvalitetnijih zadataka s obzirom } \\
\text { na kognitivne razine, za svaku od računalnih } \\
\text { provjera) }\end{array}$ \\
\hline 6. tjedan & \multicolumn{2}{|c|}{ 2. lipnja - logiranje učenika u sustav za e - učenje } & - testiranje načina pristupa e-kolegiju i \\
\hline
\end{tabular}




\begin{tabular}{|c|c|c|}
\hline TJEDAN & UČENIK & NASTAVNIK \\
\hline 1. lipnja - 6. lipnja & Loomen & $\begin{array}{c}\text { provjera postavki svake računalne provjere } \\
\text { - online praćenje rada učenika te podrška učenicima } \\
\text { koji nisu uspjeli pokrenuti provjeru znanja u prvih } \\
\text { nekoliko minuta }\end{array}$ \\
& 4. lipnja - pisanje računalnih provjera & - vrednovanje naučenog \\
& - aktivnost forum & - vrednovanje kao učenje \\
& (samovrednovanje)
\end{tabular}

Online nastava se odvijala prema uobičajenom rasporedu sati biologije. Strategije poučavanja prilagođene su uvjetima nastave na daljinu, u skladu s planiranim ishodima. S obzirom da je zbog velikog opterećenja mrežnih poslužitelja Office-a 365, Carnet Helpdesk poslao obavijest kojom se zabranjuje korištenje video poziva, za potrebe istraživanja svi sudionici su instalirali Zoom - aplikaciju za video pozive. Tijekom trajanja video poziva učenicima je prezentiran digitalni sadržaj u razrednoj bilježnici (OneNote Class Notebook), u prostoru za suradnju (engl. Collaboration space), u sekciji pod nazivom - biologija. Svaki digitalni sadržaj je osim kratkog sažetka nastavne jedinice bio dopunjen različitim audiovizualnim sadržajima (ilustracijama, slikama, video zapisima ili animacijama). Na kraju stranice nalazio se zadatak za ponavljanje ili vježbanje, kojeg su učenici trebali riješiti i poslati u svoju digitalnu bilježnicu do idućeg online sata. Rok predaje zadaće bio je u prosjeku sedam dana kako se učenike ne bi preopteretilo. Nakon nastave, svi digitalni sadržaji učenicima su stalno bili dostupni. Za vrijeme trajanja postupka, rad učenika je sustavno praćen bilješkama u e-dnevniku.

\section{REZULTATI}

Postupak pisanja računalne provjere znanja proveden je tako što su se svi učenici prijavili u sustav pet minuta prije automatskog pokretanja prve računalne provjere (srednja razina). Prva računalna provjera pisana je od 10.15 do 10.25 , a druga računalna provjera (osnovna razina ili napredna razina) od 10.25 do 10.35. Nakon zatvaranja druge računalne provjere učenici su dobili povratnu informaciju o rezultatima koja je uključivala ukupno ostvareni broj bodova (iz svake računalne provjere) te točan odgovor za svaki pojedini zadatak. Unatoč tome što su učenici logirani u sustav Loomen tjedan dana prije, dvije učenice su imale tehničkih poteškoća te nisu pristupile provjerama, a dvoje učenika je zahvaljujući online podršci, neposredno prije trenutka "otključavanja“ prve računalne provjere, uspješno logirano u sustav. U postupku je sudjelovalo ukupno 49 učenika, s tim da jedna učenica nakon prve provjere nije pristupila drugoj provjeri.

Tablica 3 Rezultati deskriptivne statistike za sve tri računalne provjere

\begin{tabular}{|c|c|c|c|c|c|c|c|c|c|c|}
\hline & Razred & $\mathrm{N}$ & M & Med. & Mod & $\begin{array}{c}\text { Frekvencija } \\
\text { moda }\end{array}$ & SD & $\begin{array}{c}\text { Koeficijent } \\
\text { varijabilnosti }\end{array}$ & Simetričnost & Zaobljenost \\
\hline \multirow{3}{*}{ 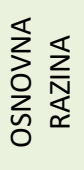 } & 1.a & 12 & 3,75 & 4 & 5 & 5 & 1,29 & 34,35 & $-0,36$ & $-1,69$ \\
\hline & 1.c & 26 & 3,23 & 3 & 3 & 9 & 1,21 & 37,46 & 0,25 & $-1,01$ \\
\hline & 1. $a+1 . c$ & 38 & 3,39 & 3 & 3 i 5 & 11 & 1,24 & 36,59 & 0,08 & $-1,33$ \\
\hline \multirow{3}{*}{ 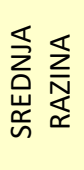 } & 1.a & 21 & 3,76 & 4 & 5 & 8 & 1,34 & 35,57 & $-0,90$ & $-0,20$ \\
\hline & 1.c & 28 & 3,36 & 3 & 3 & 9 & 1,66 & 49,50 & 0,17 & $-0,99$ \\
\hline & 1. $a+1 . c$ & 49 & 3,53 & 4 & 3 i 5 & 12 & 1,53 & 43,30 & $-0,21$ & $-0,95$ \\
\hline \multirow{3}{*}{ 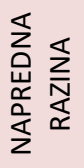 } & 1.a & 8 & 3,00 & 3 & $2,3,4$ & 2 & 1,31 & 43,64 & 0,00 & $-0,70$ \\
\hline & 1.c & 2 & 3,00 & 3 & 3 & 2 & 0 & 0 & - & - \\
\hline & 1. $a+1 . c$ & 10 & 3,00 & 3 & 3 & 4 & 1,15 & 38,49 & 0,00 & 0,08 \\
\hline
\end{tabular}


Prema podatcima iz tablice 3 razvidno je da je nakon prve računalne provjere 38 učenika (79\%), odabralo računalnu provjeru osnovne razine. Međutim, unatoč postavljenoj hipotezi učenici nisu najbolje riješili računalnu provjeru osnovne razine, već onu srednje razine $(M=3,53)$, iako je razlika s obzirom na ostvareni broj bodova između te dvije razine neznatna. Kada se uzme u obzir da je maksimalni broj bodova u svakoj računalnoj provjeri iznosio osam, iznenađuje da ni u jednoj računalnoj provjeri, prema aritmetičkoj sredini, učenici nisu uspjeli ostvariti $50 \%$ riješenost. Od maksimalno osam bodova, raspon postignutih bodova kretao se između jedan i šest bodova. Kao što se vidi na slici 1, u računalnoj provjeri srednje razine najveći broj učenika postigao je tri i pet bodova. $U$ analizi moda primjetno je da su vrijednosti moda veće kod računalne provjere osnovne i srednje razine u odnosu na računalnu provjeru napredne razine. S obzirom da je svaka provjera sadržavala samo osam zadataka, vrijednosti medijana pokazuju malu varijabilnost te su slične vrijednostima aritmetičkih sredina.

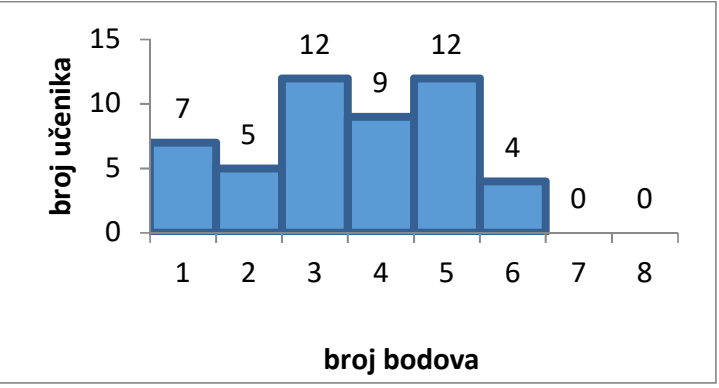

Slika 1 Raspodjela ostvarenog broja bodova prema broju učenika za računalnu provjeru srednje razine

Ako se usporede postignuća učenika pri rješavanju računalne provjere osnovne i srednje razine $s$ obzirom na točnost odgovora u svakom od osam zadataka, uočavaju se odstupanja u skladu s težinom zadatka. lako se aritmetičke sredine neznatno razlikuju, u računalnoj provjeri srednje razine učenici su veći broj zadataka uspješno riješili. lako je u računalnoj provjeri osnovne razine u 1. zadatku utvrđen visok indeks lakoće $(p=0,95)$ kao i u 7. zadatku $(p=0,92)$, ostali zadaci su učenicima bili teški. Usporedba indeksa lakoće na slici 2 pokazuje da je računalna provjera srednje razine ipak sadržavala bolje konstruirane zadatke koji učenicima nisu bili ni prelagani ni preteški.

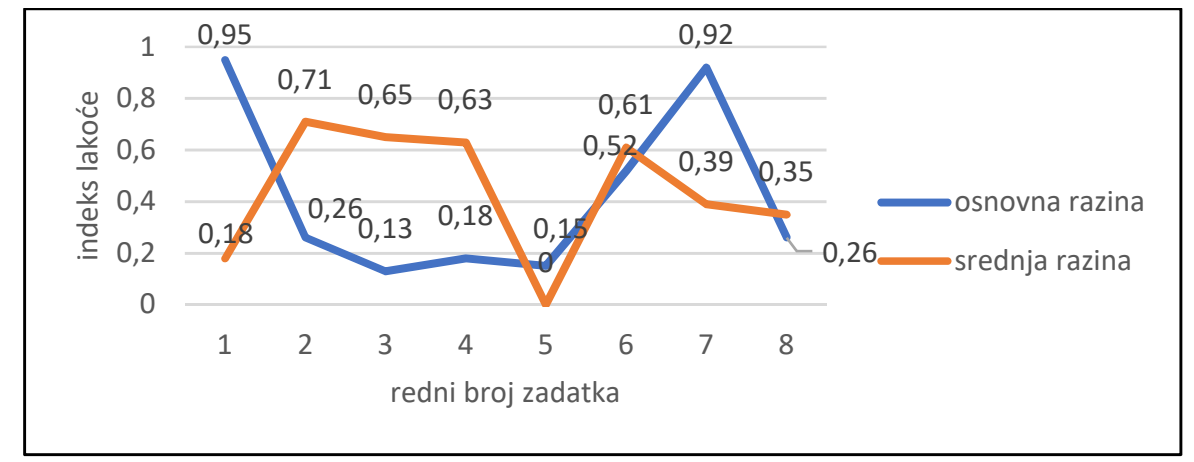

Slika 2 Usporedba indeksa lakoće zadataka između računalne provjere osnovne i srednje razine

Sveukupno loša riješenost svih računalnih provjera može se pripisati kognitivno zahtjevnijim zadacima, odnosno korištenju zadataka koji ne provjeravaju samo prvu kognitivnu razinu - znanje reprodukcije. U skladu s postavljenom hipotezom učenici su u sve tri računalne provjere najbolje riješili zadatke prve kognitivne razine.

Ipak, sukladno težini računalne provjere opada i riješenost takvih zadataka. Na slici 3 evidentno je da su učenici u računalnoj provjeri osnovne razine riješili 54,59 \%, u provjeri srednje razine $41,05 \%$, a u provjeri napredne razine svega $40 \%$ zadataka koji provjeravaju prvu kognitivnu razinu. 


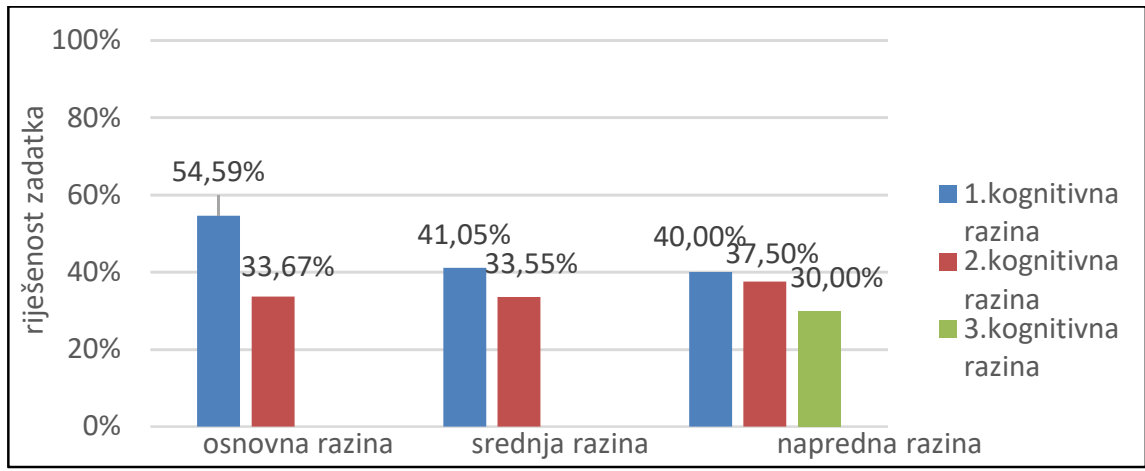

Slika 3 Usporedba riješenosti zadataka s obzirom na kognitivne razine

Što se tiče pojedinačno svake računalne provjere, statistička obrada pokazuje da izostaje linearna distribucija rezultata. Na slici 2, koja se odnosi na računalnu provjeru srednje razine, uočava se raspodjela rezultata koja je razmjerno simetrična, ali nije normalna ( $p$-vrijednosti Shapiro-Wilkova i Lilieforsova testa su manje od 0,05 ) zbog čega je odlučeno da se $u$ daljnjim analizama koriste također neparametrijski testovi. Kako bi se utvrdilo postoji li korelacija između postignuća učenika i broja sati koje je utrošeno za online poučavanje izračunat je Spearmanov koeficijent korelacije te je utvrđeno da ne postoji statistički značajna povezanost između broja sati nastave na daljinu i rezultata računalne provjere srednje razine $(r=0,14, p>0,05)$. Za utvrđivanje utjecaja broja sati online poučavanja na ostvareni broj bodova proveden je Mann-Whitney $(U)$ test, gdje dobivene vrijednosti $(U=0,97$ i $p=$ $0,33)$ ukazuju da nema statistički značajne razlike. lako su učenici 1. a razreda tjedno imali jedan školski sat više od učenika 1. c razreda, veći broj sati nastave nije utjecao na veću uspješnost učenika. U tablici 4 prikazani su rezultati statističke obrade te je ujedno utvrđeno da između zaključne ocjene iz biologije i rezultata računalne provjere srednje razine postoji statistička značajna umjerena povezanost $(r=0,51$, $p<0,05)$.

Tablica 4 Rezultati Spearmanova koeficijenta korelacije $(r)$ između odabranih varijabli $(* p<0,05)$

\begin{tabular}{|c|c|}
\hline & Rezultat računalne provjere - srednja razina \\
\hline Zaključna ocjena predmeta biologija & $0,51^{*}$ \\
\hline Broj školskih sati online poučavanja & 0,14 \\
\hline
\end{tabular}

Povezanost broja ostvarenih bodova $s$ zaključnom ocjenom predmeta može se pripisati osobnoj jednadžbi nastavnika prema kojoj se metodologija vrednovanja nastavnika odražava u učeničkim postignućima. S obzirom da autorice primjenjuju kriterijsko vrednovanje i u ostalim aktivnostima vrednovanja naučenog, ova pozitivna korelacija je bila očekivana.

\section{RASPRAVA}

Provedenim istraživanjem tri hipoteze su potvrđene, a dvije su odbačene. Kada učenici imaju mogućnost izbora najčešće biraju lakšu varijantu računalne provjere, u svim računalnim provjerama znanja učenici najuspješnije rješavaju zadatke prve kognitivne razine, a postignuća učenika u računalnoj provjeri srednje razine u korelaciji su s zaključnom ocjenom iz biologije. Suprotno tome najveća riješenost nije ostvarena u računalnoj provjeri osnovne razine niti su postignuća učenika u korelaciji s brojem sati utrošenih za online poučavanje. Ove dvije hipoteze su odbačene.

Najveći nedostatak u korištenju računalnih provjera je svakako oblikovanje zadataka. Za potrebe istraživanja odabran je tip zadatka višestrukog izbora s jednim točnim odgovorom kako bi se izbjegle poteškoće pri bodovanju pitanja otvorenog tipa. $\mathrm{S}$ druge strane, kod pitanja višestrukog izbora ne smije se zanemariti da su faktori koji umanjuju njihovu kvalitetu - nedovoljno kvalitetni homogeni distraktori i mogućnost pogađanja točnog odgovora (Begić i sur, 2019). Tome svakako treba pridodati 
i mogućnost prepisivanja u digitalnom okruženju koja se ograničavanjem vremena na deset minuta pokušala spriječiti. lako se očekivala najveća riješenost u računalnoj provjeri osnovne razine očigledno je da su bolje konstruirani zadaci u računalnoj provjeri srednje razine doveli do najbolje riješenosti. Sukladno očekivanjima učenici su u svim računalnim provjerama najbolje riješili zadatke prve kognitivne razine. Na slici 3 evidentno je da iako je računalna provjera srednje razine sadržavala isti omjer zadataka prve i druge kognitivne razine, zadatke prve razine je riješilo 41,05 \% u odnosu na 33,55 $\%$ druge razine.

Unatoč pažljivo planiranim aktivnostima poučavanja, asinkrono - korištenjem digitalnih sadržaja u digitalnoj bilježnici (OneNote Class Notebook) i sinkrono - korištenjem video poziva, odgojno-obrazovni ishodi nisu ostvareni na očekivanoj razini, što znači da nastava na daljinu donosi ograničenja koja utječu na kvalitetu poučavanja i kvalitetu stečenih znanja i vještina. Usvajanje koncepata razmnožavanja i nasljeđivanja tijekom oplodnje očigledno zahtijevaju interakciju licem u lice koja nastavniku može daleko bolje pružiti dokaze o usvojenosti navedenih odgojno-obrazovnih ishoda na temelju kojih se onda planira buduće poučavanje. Tome u prilog ide i podatak iz tablice 4 po kojem broj sati online poučavanja nije utjecao na postignuća učenika. Jedan od mogućih uzroka lošijih postignuća može se naći i u miskonceptima s kojima učenici dolaze iz osnovne škole, a odnose se upravo na ishode koji su bili provjeravani online. Rezultati analize pitanja koja su provjeravali slične ishode $s$ županijskih natjecanja iz biologije za sedmi i osmi razred iz 2015. i 2017. godine potvrđuju ove indicije (Golubić i sur, 2017).

Ono što svakako treba istaknuti je statistički značajna povezanost između postignuća učenika iz računalnih provjera i zaključne ocjene predmeta $(r=0,51, p<0,05)$, što implicira mogućnost veće primjene online vrednovanja za potrebe formativnog i sumativnog vrednovanja. Ipak, zbog brojnih varijabli koje mogu umanjiti valjanost, osjetljivost i pouzdanost računalne provjere kao mjernog instrumenta, većina autora naglašavaju formativnu svrhu (Stödberg, 2012). Korištenje računalnih provjera za samovrednovanje ima niz prednosti: manje kognitivno opterećenje, brza i kvalitetna povratna informacija, bogatstvo elemenata i funkcija sučelja, adaptivno testiranje, pristupačnost, automatizirana obradba rezultata i pružanje pravovremene povratne informacije, ušteda vremena i ljudskih resursa te pozitivne razlike u ostvarenim ishodima učenja (Petrović, 2017, str. 2). lako je zabilježena pozitivna korelacija između učestalosti korištenja računalnih formativnih provjera $\mathrm{i}$ rezultata ostvarenih na sumativnim provjerama (Dobson, 2008; Grimstad i Grabe, 2014, prema Petrović, 2017, McDaniel i sur, 2012), ova relacija zahtijeva dodatne analize.

Na kraju, potvrđena je hipoteza prema kojoj, kada imaju mogućnost izbora, učenici biraju računalnu provjeru koja je kognitivno najmanje zahtjevna. Nakon prve računalne provjere $79 \%$ učenika je odabralo osnovnu razinu, a $21 \%$ učenika naprednu razinu što je još jedna potvrda nužnosti individualiziranog pristupa. Nastavnik bi pri planiranju poučavanja trebao odabrati prikladne metode vrednovanja koje bi zatim trebao diferencirati u skladu s različitim potrebama, sposobnostima i interesima učenika. To bi se lako moglo realizirati izradom digitalne banke zadataka s pitanjima različitih razina zahtjevnosti i različitim varijantama računalnih provjera. U nekom budućem istraživanju, takvim provjerama znanja mogla bi se provjeriti usvojenost ishoda na uzorku pojedinih učenika ili grupa učenika.

\section{ZAKLUČAK}

Provedeno istraživanje potvrdilo je da računalne provjere kao metoda u vrednovanju naučenog imaju prednosti i nedostatke. $U$ uvjetima nastave na daljinu brze računalne provjere mogu nastavniku dati 
korisne informacije o razini ostvarenosti odgojno-obrazovnih ishoda. Ukoliko se koriste za sumativno vrednovanje nastavnik treba konstruirati zadatke koji će provjeravati različite kognitivne razine, vodeći računa o tome da zadaci nisu ni prelagani, ni preteški. Istraživanje je pokazalo da čak i uz pažljivo planirane aktivnosti online poučavanja, nastava na daljinu nije pokazala željene rezultate, odnosno postotak riješenosti u sve tri računalne provjere je bio manji od $50 \%$, a učenici najbolje rezultate ostvaruju u pitanjima razine reprodukcije. Vrijeme utrošeno na poučavanje, odnosno broj sati koje nastavnik koristio za poučavanje nije utjecalo na postignuća učenika.

\section{METODIČKI ZNAČAJ}

Rezultati ovog istraživanja mogu poslužiti kao smjernice u budućoj nastavi na daljinu jer opisuju prednosti i nedostatke računalnih provjera kao nove metode vrednovanja. Međutim, unatoč pažljivo planiranim aktivnostima poučavanja, koje su uključivale multimedijske obrazovne sadržaje i razrednu bilježnicu (OneNote Class Notebook), realizacija pojedinih koncepata i ishoda kurikuluma biologije u uvjetima nastave na daljinu zahtijeva neke nove modele učenja i poučavanja. Očigledno je da se proces poučavanja i vrednovanja ne može preslikati iz učionice u digitalno okruženje - bez odgovarajućih prilagodbi. To se naročito odnosi na pristup vrednovanja naučenog koje zahtijeva više razinu digitalnih i metodičkih kompetencija pri osmišljavanju zadataka različitih kognitivnih razina.

Mogućnost primjene računalnih provjera $u$ diferencijaciji vrednovanja ima svoje uporište $u$ programskoj podršci platforme za učenje Loomen koja nastavniku omogućava izradu banke zadataka i kreiranje računalnih provjera znanja koje se mogu prilagoditi različitim potrebama učenika. Također, uvidom u rezultate računalnih provjera nastavnik dolazi do povratne informacije o uspješnosti korištenih strategija poučavanja i ovisno o tome može planirati daljnje aktivnosti.

\section{LITERATURA}

Alruwais, N., Wills., G, Wald, M. (2018). Advantages and Challenges of Using e-Assessment International Journal of Information and Education Technology, 8, (1): 34-37.

Andersen, L. W. (2002). Curricular alignment: A re-examination. Theory Into Practice, 41(4): $255-260$.

Begić, V., Radanović, I., Pongrac-Štimac Z., Bastić, M., Garašić, D., Lukša, Ž., Kapov, S., Ništ, M. (2019). Oblikovanje pisane provjere iz biologije. Preporuke za pripremu zadataka i konstrukciju pisane provjere, Zagreb, Hrvatsko biološko društvo.

Begić, V., Bastić, M., Radanović, I. (2016). Utjecaj biološkog znanja učenika na rješavanje zadataka viših kognitivnih razina. Educatio biologiae, 2:13-42.

Blaće, A., Marin, G., Fabac, S. (2019). TEST JEZGRA, Loomen online tečaj Dostupno na: https://loomen.carnet.hr/course/view.php?id=12349, pristupljeno 27.4.2020.

Bulić, M. (2018). Sustavi e-učenja u promicanju obrazovanja za zdrav i održiv život. Doktorski rad. Sveučilište u Splitu, PMF.

Bulić, M. (2018a). Ostvarenost ishoda učenja biologije u sustavu e-učenja. Educatio biologiae, 4: 56-68.

Buzzetto-More, N. A., Alade, A. J. (2006). Best Practices in e-Assessment,

Journal of Information Technology Education, 5 (1): 251-269.

Cassady, J. C., Gridley, B. E. (2005). The Effects of Online Formative and Summative Assessment on Test Anxiety and Performance, The Journal of Technology, Learning, and Assessment, 4 (1).

Crooks, T. J. (1988). Impact of classroom evaluation on student. Review of Education Research, 58(4): $438-481$.

Dermo, J. (2009). E-Assessment and the student learning experience: A survey of student perceptions of e-assessment. British Journal of Educational Technology, 40 (2): 203-214.

Dobson, J. L. (2008). The use of formative online quizzes to enhance class preparation and scores on summative exams. Advances in Physiology Education, 32: 297-302.

Eurydice, (2018). Obrazovanje i osposobljavanje odgojitelja, učitelja i nastavnika (European Commission), Dostupno na: https://eacea.ec.europa.eu/national-policies/eurydice/content/initial-education-teachers-working-early-childhood-and-school-education$14 \mathrm{hr}$, pristupljeno 15.7.2020.

Golubić, M., Begić, V., Lukša, Ž., Korać, P., Radanović, I. (2017). Razumijevanje životnog ciklusa i oplodnje tijekom učenja biologije u osnovnoj školi. Educatio biologiae, 3 (1): 76-99.

Grgin, T. (1994). Školska dokimologija, Jastrebarsko, Naklada slap.

Grgurić, I., Begić, V., Bastić, M., Lukša, Ž., Radanović, I. (2017). Kvaliteta pitanja i uspjeh srednjoškolskih sudionika natjecanja iz biologije u znanju. Educatio biologiae, 3 (1): 32-56. 
Howarth, P. (2015). The opportunities and challenges faced in utilizing e-Based assessment. EAssessment in Higher Education: A Review. Dostupno na: https://www.researchgate.net/publication/329775612 EAssessment in Higher Education A Review, pristupljeno 17.2. 2020.

Ivić, J., Tomaš, S. (2017). Privatna poduka učenika osnovne škole u Moodleu. Dostupno na: https://radovi.cuc.carnet.hrDubrovnik 110, pristupljeno 17.2.2020.

Jukić, R. (2013). Konstruktivizam kao poveznica poučavanja sadržaja prirodoznanstvenih i društvenih predmeta. Pedagogijska istraživanja, 10 (2): $241-263$.

Jugo, G., Matotek, I., Carev, M., Dumovic, D. (2012). Uporaba Moodle-a 2.0 u vrednovanju znanja. Medijska istraživanja, 18 (1):153-162.

Kokan, N., Tomić, J., Grubišić, A. (2014). Sustav Moodle u nastavi hrvatskog jezika. Školski vjesnik, 63 (3): 367-379.

Kotzer, S., Elran, Y. (2012). Learning and teaching with Moodle-based E- learning environments, combining learning skills and content in the fields of Math and Science \& Technology, 1st Moodle Research Conference, 122-131.

Matijević, M., Topolovčan, T. (2017). Multimedijska didaktika, Zagreb, Školska knjiga.

McDaniel, M. A., Wildman, K. M., Anderson, J. L. (2012). Using quizzes to enhance summative-assessment performance in a web-based class: An experimental study. Journal of Applied Research in Memory and Cognition, 1 (1):18-26.

MPIŠ RH (1997). Nastavni plan i program za strukovne škole, Glasnik Ministarstva prosvjete i športa Republike Hrvatske. Dostupno na: http://dokumenti.ncrvo.hr/Nastavni plan/strukovne/biologija.pdf, pristupljeno 15.2.2020.

MZO (2019). Odluka o donošenju kurikuluma za nastavni predmet biologije za osnovne škole i gimnazije u Republici Hrvatskoj (NN 7/2019), Dostupno na: https://narodne-novine.nn.hr/clanci/sluzbeni/2019 017 149.html, preuzeto 13. 10. 2019.

NCVVO (2020). Ispitni katalog za državnu maturu u školskoj godini 2019/2020, Dostupno na: https://mkOncvvot6usx5xu4d.kinstacdn.com/wp-content/uploads/2019/10/BIOLOGIJA-2020.pdf, 14.1.2020.

Petrović, J. (2017). Automatizirano vrednovanje dijagnostičkih vještina zasnovano na ispitanikovom oblikovanju pravila za rješavanje scenarijskih problemskih zadataka. Doktorska disertacija, Fakultet elektrotehnike i računarstva, Zagreb.

Radanović, I., Lukša, Ž., Begić, V., Sertić-Perić, M., Garašić, D. (2018). Professional quality assessment of the Croatian state written exam in biology. Proceedings of the ESERA 2017 Conference. Research, Practice and Collaboration in Science Education. Part Evaluation and assessment of student learning and development 11/11 (co-ed. Dolin, J.), 1522-1530. Dublin, Ireland.

Radanović, I., Bastić, M., Begić, V., Kapov, S., Sumpor, D., Mustać, A. (2013). Preporuke za autore i recenzente provjera natjecanja u znanju biologije. Hrvatsko biološko društvo. Dostupno na: http://www.hbd-sbc.hr/wordpress/wpcontent/uploads/2013/06/Preporuke-za-autore-irecenzente-natjecanja-20131.pdf, pristupljeno 15.2.2020.

Ristić Dedić, Z., Jokić, B., Šabić, J. (2011). Analiza sadržaja i rezultata ispita državne mature iz biologije. Nacionalni centar za vanjsko vrednovanje obrazovanja, Institut za društvena istraživanja u Zagrebu.

Stödberg, U. (2012). A Research Review of E-Assessment. Assessment \& Evaluation in Higher Education, 37(5): 591-604.

Tomaš, S. (2018). Digitalne tehnologije kao potpora praćenju i vrednovanju, priručnik, Hrvatska akademska i istraživačka mreža CARNET.

\section{PRILOZI}

Prilog 1 Pitanja u tri računalne provjere (*zadatak 1. kognitivne razine, ** zadatak 2 . kognitivne razine, *** zadatak 3. kognitivne razine)

\begin{tabular}{|c|c|c|}
\hline osnovna razina & srednja razina & napredna razina \\
\hline $\begin{array}{l}1^{*} \text {. Koji od navedenih organizama } \\
\text { nema jezgru? } \\
\text { a) papučica } \\
\text { b) bakterija } \\
\text { c) zelena alga } \\
\text { d) plijesan }\end{array}$ & $\begin{array}{l}\text { 1*. Što od navedenog ne sadrži stanična } \\
\text { jezgra? } \\
\text { a) ovojnicu } \\
\text { b) proteinske pore } \\
\text { c) dvostruku membranu } \\
\text { d) male kružne molekule DNA }\end{array}$ & $\begin{array}{l}1^{*} \text {.Koja se od navedenih molekula transportira } \\
\text { iz jezgre u citoplazmu? } \\
\text { a) DNA } \\
\text { b) m RNA } \\
\text { c) histoni } \\
\text { d) enzimi za transkripciju }\end{array}$ \\
\hline $\begin{array}{l}2^{*} \text {. Koliko kromosoma sadrži jezgra } \\
\text { u stanici kože čovjeka? } \\
\text { a) } 23 \\
\text { b) } 22+x \\
\text { c) } 44+x x \\
\text { c) } 44\end{array}$ & $\begin{array}{l}2^{*} \text {. Koju fazu mejoze prikazuje } \\
\text { slika? } \\
\text { a) interfaza } \\
\text { b) profaza II } \\
\text { c) profaza I } \\
\text { d) prometafaza }\end{array}$ & $\begin{array}{l}2^{*} \text {. Koliki je ukupni zbroj molekula DNA drugog, } \\
\text { petog i sedmog para kromosoma u profazi } \\
\text { stanice jetre? } \\
\text { a) } 3 \\
\text { b) } 6 \\
\text { c) } 12 \\
\text { d) } 24\end{array}$ \\
\hline $\begin{array}{l}\text { 3*. Koju fazu mitoze prikazuje } \\
\text { slika? } \\
\text { a) metafaza } \\
\text { b) anafaza } \\
\text { c) telofaza } \\
\text { d) profaza }\end{array}$ & $\begin{array}{l}\text { 3*. U kojoj se fazi interfaze broj molekula } \\
\text { DNA, u stanici kože čovjeka, poveća s } 46 \text { na } \\
92 \text { ? } \\
\text { a) G1 } \\
\text { b) S } \\
\text { c) G2 } \\
\text { d) G0 }\end{array}$ & $\begin{array}{l}\text { 3*.U koju staničnu strukturu ulazi mRNA nakon } \\
\text { izlaska iz jezgre? } \\
\text { a) glatki ER } \\
\text { b) hrapavi ER } \\
\text { c) mitohondrij } \\
\text { d) Golgijevo tijelo }\end{array}$ \\
\hline
\end{tabular}




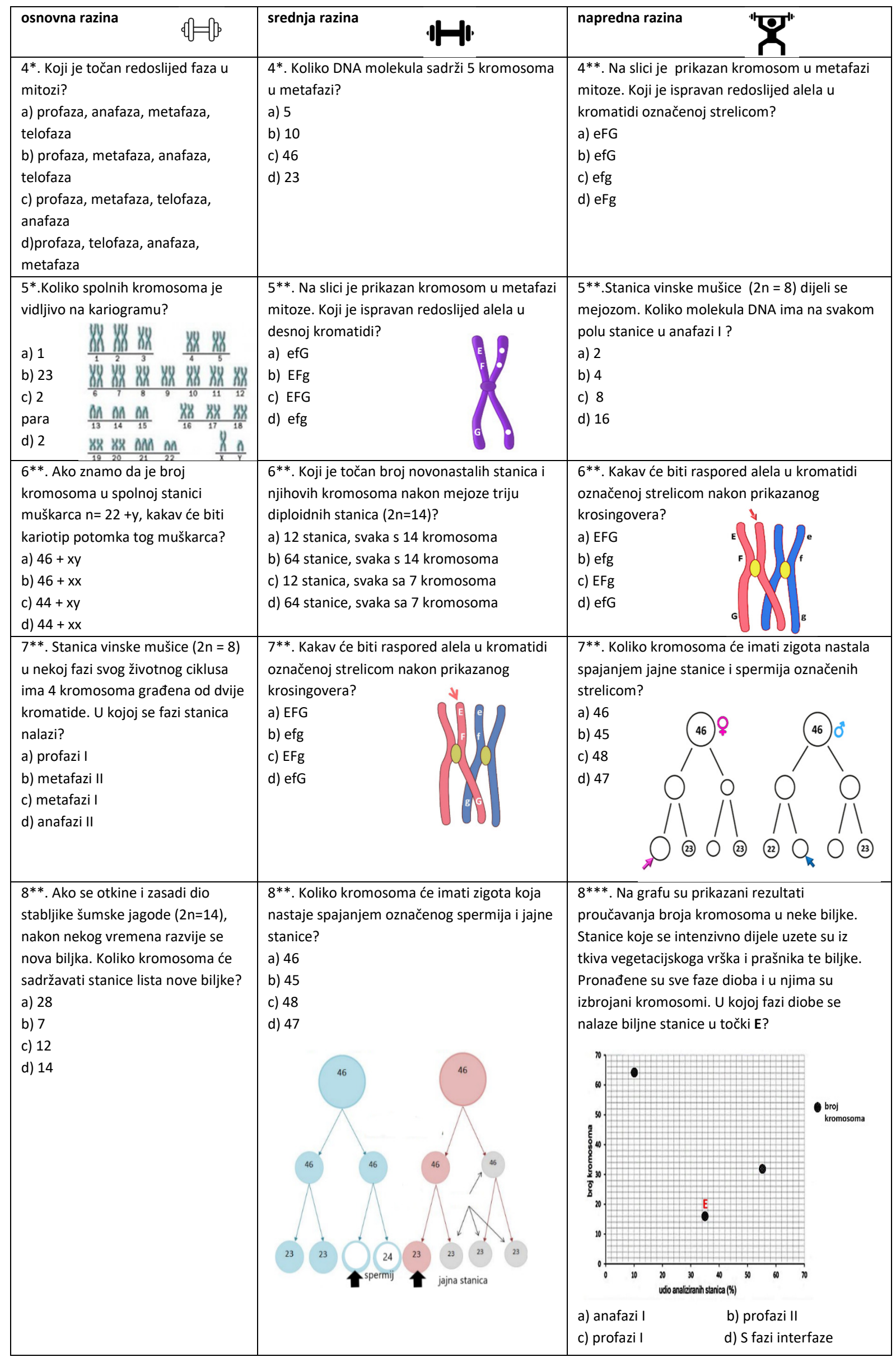




\title{
Design of computer based exams with Moodle platform in the context of differentiated assessment
}

\author{
Gabrijela Marin ${ }^{1}$, Sanja Fabac ${ }^{2}$ \\ ${ }^{1}$ Ante Kuzmanić Medical School, Zadar, Republic of Croatia \\ gabrijela.marin@skole.hr \\ 2 Public high school/grammar school - Gimnazija Vladimira Nazora, Zadar, Republic of Croatia
}

\begin{abstract}
A survey was conducted during the period of online teaching (school year 2019. / 2020.) on a sample of 49 students of two first grade at the Ante Kuzmanic Medical School, in Zadar. The aim of the study was to explore computer-based exams as assessment method at assessment of learning, in the period of pandemic. Over the period of four weeks, students were taught online; asynchronously-through digital content in OneNote Class Notebook and synchronously using video calls. The efficiency of online teaching had been checked by three computer-based exams, in time limited conditions, using Moodle. Each exam had precisely determined ratio of questions with different cognitive levels. After the students had taken their first online exam - level medium, they had to choose one of two other exams: level - basic or level - advanced. The results indicate that despite carefully planned instructional procedures, online teaching had a poor impact on student's learning outcomes, because students' achievement in every exam was lower than $50 \%$. Contrary to the hypothesis students are most successful in first online exam (level - medium) and number of hours of online teaching had no effect on a student's achievement. Accordant to the hypothesis students are most successful in solving the questions of the first cognitive level. Nevertheless, considering these findings, by using the learning platform Moodle, the teacher can create a test bank what opens the possibility for differentiation of assessment process, accordant to different learning needs and interests of students.
\end{abstract}

Keywords: computer-based exams; assessment of learning; cognitive level; differentiation; Moodle 